\title{
Identification and mapping of the nursing diagnoses and actions in an Intensive Care Unit ${ }^{1}$
}

\author{
Patrícia de Oliveira Salgado² \\ Tânia Couto Machado Chianca ${ }^{3}$
}

This is a descriptive study with the aim of examining the nursing diagnoses labels and actions prescribed by nurses in the clinical records of patients hospitalized in an Adult Intensive Care Unit. A sample of 44 clinical records was obtained and a total of 1087 nursing diagnoses and 2260 nursing actions were identified. After exclusion of repetitions 28 different nursing diagnoses labels and 124 different nursing actions were found. Twentyfive nursing diagnoses labels were related to human psychobiological needs and three to psychosocial needs. All the nursing actions were mapped to the physiological needs and also to interventions of the Nursing Interventions Classification-NIC. Concordance of $100 \%$ was obtained between the experts in the validation process of the mapping performed, both for the nursing diagnoses labels and actions. Similar studies should be conducted for the identification and development of nursing diagnoses and actions.

Descriptors: Nursing; Nursing Process; Classification; Intensive Care Units; Adult.

\footnotetext{
${ }^{1}$ Paper extrated from Master's Dissertation "Identificação e mapeamento dos diagnósticos e ações de enfermagem de pacientes internados em uma UTI-Adulto" presented to Escola de Enfermagem, Universidade Federal de Minas Gerais, Belo Horizonte, MG, Brazil.

${ }^{2}$ RN, Hospital Municipal Odilon Behrens, Belo Horizonte, MG, Brazil. Doctoral Student in Nursing, Escola de Enfermagem, Universidade Federal de Minas Gerais, Belo Horizonte, MG, Brazil. E-mail: patriciaoliveirasalgado@gmail.com.

${ }^{3}$ RN, Ph.D. in Nursing, Associate Professor, Escola de Enfermagem, Universidade Federal de Minas Gerais, Belo Horizonte, MG, Brazil. E-mail: taniachianca@gmail.com.
}

Corresponding Author:

Tânia Couto Machado Chianca

Universidade Federal de Minas Gerais. Escola de Enfermagem. Departamento

de Enfermagem Básica

Av. Alfredo Balena, 190

Bairro: Santa Efigênia

CEP: 30130-100, Belo Horizonte, MG, Brasil

E-mail: taniachianca@gmail.com 


\title{
Identificação e mapeamento dos diagnósticos e ações de enfermagem em Unidade de Terapia Intensiva
}

Trata-se de estudo descritivo com o objetivo de analisar os registros dos títulos diagnósticos e as ações de enfermagem prescritas por enfermeiros, nos prontuários de pacientes internados em uma unidade de terapia intensiva de adultos. Obteve-se amostra de 44 prontuários. Identificaram-se 1.087 diagnósticos e 2.260 ações de enfermagem. Após exclusão de repetições, foram encontrados 28 diferentes títulos diagnósticos e 124 diferentes ações de enfermagem. Vinte e cinco títulos diagnósticos estão relacionados às necessidades humanas psicobiológicas e três às necessidades psicossociais. Todas as ações de enfermagem foram mapeadas às necessidades psicobiológicas e, também, às intervenções da classificação das intervenções de enfermagem-NIC. Obteve-se $100 \%$ de concordância entre os expertos, no processo de validação do mapeamento realizado, tanto dos títulos diagnósticos quanto das ações de enfermagem. Estudos semelhantes devem ser conduzidos para a identificação e evolução de diagnósticos e ações de enfermagem.

Descritores: Enfermagem; Processos de Enfermagem; Classificação; Unidades de Terapia Intensiva; Adulto.

\section{Identificación y mapeo de los diagnósticos y acciones de enfermería en Unidad de Terapia Intensiva}

\begin{abstract}
Se trata de un estudio descriptivo con el objetivo de analizar los registros de los títulos de diagnóstico y las acciones de enfermería prescritas por enfermeros en las fichas de pacientes internados en una Unidad de Terapia Intensiva de Adultos. Se obtuvo una muestra de 44 fichas. Se identificaron 1.087 diagnósticos y 2.260 acciones de enfermería. Después de la exclusión de repeticiones se encontró 28 diferentes títulos de diagnóstico y 124 diferentes acciones de enfermería. Veinte y cinco títulos de diagnóstico están relacionados a las necesidades humanas psicobiológicas y tres a las necesidades psicosociales. Todas las acciones de enfermería fueron mapeadas a las necesidades psicobiológicas y también a las intervenciones de la Clasificación de las Intervenciones de Enfermería-NIC. Se obtuvo 100\% de concordancia entre los expertos en el proceso de validación del mapeo realizado, tanto de los títulos de diagnóstico como de las acciones de enfermería. Estudios semejantes deben ser conducidos para la identificación y evolución de diagnósticos y acciones de enfermería.
\end{abstract}

Descriptores: Enfermería; Procesos de Enfermería; Clasificación; Unidades de Terapia Intensiva; Adulto.

\section{Introduction}

Nursing care is specific professional work with dynamic and inter-related actions for its achievement; it implies the adoption of a particular way of caring, based on a way of thinking - the Nursing Process (NP) ${ }^{(1)}$. The standardization of the nursing language for problems and treatments has been developed to clarify and communicate some essential rules in the care implementation(2). Despite this effort, there are still many problems and nursing treatments that have not yet been standardized. In healthcare practice the need is perceived to instrumentalize the nurses to implement the NP more effectively and with systematized actions. This reality has a greater impact, especially in Intensive Care Units (ICU) due to the fact that critical and rapid evaluations of the patients are necessary, as well as comprehensive care plans, services well coordinated with other health 
professionals, and convenient and effective planning for discharge ${ }^{(3)}$.

In an Adult ICU of Belo Horizonte, MG, the steps of the NP have been implemented since 2006, using as the theoretical framework the Basic Human Needs (BHN) theory ${ }^{(4)}$. However, unlike the nursing diagnoses developed for hospitalized patients in this service, using as a reference the Taxonomy II of the North American Nursing Diagnoses Association (NANDA-I) ${ }^{(5)}$, the prescribed nursing care is proposed based on the experience and knowledge of the nurses, supported by specific literature, without any classification structure of nursing interventions being used as a reference. In addition, the prescribed nursing actions are not directly related to the nursing diagnoses formulated. This has raised concern and the need to know the nursing diagnoses formulated and the nursing actions prescribed for the patients and, from the terms employed, using the technique of cross-mapping, to describe the $\mathrm{BHN}^{(4)}$ and nursing interventions established in the related Nursing Interventions Classification (NIC) ${ }^{(2)}$.

This study is justified considering that the use of a set of nursing diagnoses and actions can represent an important tool for implementing Nursing Care Systematization (NCS) in units where the nurse provides care, especially in the ICU. The study is relevant for the importance of developing nursing databases that support the measurement and quality of health (efficacy) in Brazil. Furthermore, this work will be integrated into software that will assist in the NCS in the ICU area, which is under construction.

This study aims to analyze the nursing diagnoses records and actions prescribed by nurses in the clinical records of patients hospitalized in an Adult ICU in Belo Horizonte (MG) from the identification of nursing diagnoses labels and actions established by nurses in the clinical records of the patients; the mapping of the nursing diagnoses labels and actions both to the Theory of $\mathrm{BHN}$ and to the nursing interventions proposed by the NIC, and to validate the nursing diagnoses labels and actions mapped together with the intensive care nurses, and researchers of the NCS area.

\section{Methods}

This is a descriptive study developed in an Adult ICU of Belo Horizonte (MG), equipped with 10 beds for private or health insurance funded care.

\section{Population and Sample}

All patients hospitalized in the ICU during the period from 1 September 2008 to 30 September, 2009, were considered the population, totaling 494 patients. The choice of this data collection period was because all phases of the NP were already implemented in the unit in this period. To estimate the representativity of the nursing diagnoses and actions sampled in relation to the 494 patients the permutation resampling method(6) was used and the algorithm was constructed using the free software $R^{(7)}$. The sample consisted of 44 patients who represented $9 \%$ of the population, which allowed the percentage to be estimate of the nursing diagnoses formulated and nursing actions prescribed.

\section{Data Collection}

Data collection consisted of four steps. In the first step the extraction of the content of the nursing diagnoses and nursing care plans from the clinical records was performed. The nursing diagnoses and actions required from the time of admission until the discharge of patients were considered, since, given the severity of the disease to which they were suffering, there could be significant change throughout the period of hospitalization in the unit. In the following (second) step the elimination of repetitions was carried out. A total of 1087 nursing diagnoses and 2260 nursing actions were collected and inserted into an Excel for Windows for Windows spreadsheet and subjected to correction of spelling, appropriateness of verb tenses, uniformity of genre and number, and exclusion of repetitions, synonyms and pseudo-terminological expressions, defined as elements that casually occur in the discourse, but that do not designate particular concepts, being considered "junk terminology"(8). In a third stage mapping was carried out of the nursing diagnoses labels and actions identified to the BHN Theory and the nursing actions were also mapped to the Nursing Interventions proposed by the $4^{\text {th }}$ edition of the NIC. The cross-mapping process is a methodological approach that links words of similar or equal sense, through a process of decision making, using inductive or deductive strategies ${ }^{(9)}$. In this study a crossmapping model was employed to link actions contained in the clinical records with the NIC Interventions ${ }^{(10)}$. In the fourth step the validation was conducted of the nursing diagnoses labels and of the nursing actions mapped to the BHN Theory and interventions proposed by the NIC in two moments. Firstly, the nursing diagnoses labels and actions mapped underwent a process of analysis and confirmation by researchers from a center of studies and research on the topic. In the second moment, the nursing diagnoses labels and actions mapped, confirmed in the first moment, underwent a process of validation by expert nurses. 
As a strategy for evaluating the mapping process, performed in the second moment of validation, the validation with experts, the Delphi technique was used, being a method to obtain the consensus of a group of experts regarding a determined theme ${ }^{(11)}$. There is no guideline to determine the adequate level of consensus to be achieved(12), however, obtaining at least $70 \%$ concordance in the final step of the Delphi Technique is recommended ${ }^{(13-14)}$. Given this recommendation, the rate of $70 \%$ was adopted as the minimum level of consensus to be reached by the experts in this study. In this process, four instruments were used: a first instrument with the necessary guidelines and the definitions of the $\mathrm{BHN}^{(15)}$; a second listed the nursing diagnoses labels collected and mapped to the BHN Theory; a third with the nursing actions mapped to the BHN Theory; and a fourth instrument with the nursing actions mapped to the NIC Interventions.

To perform the validation of the mapping of the nursing diagnoses labels and actions by experts, 11 nurses were invited by email. Upon receiving the invitation, all the professionals agreed to participate and received, by email, the material of the first validation stage (the Terms of Free Prior Informed Consent -TFPIC, the instrument with the necessary guidance and with the definitions of the $\mathrm{BHN}$, the instrument with the nursing diagnoses labels collected and mapped to the BHN Theory, the instrument with the nursing actions mapped to the BHN Theory and a stamped addressed envelope for the return of the signed TFPIC). After the return of the instruments validated in the first stage, the nurses were forwarded them with the nursing actions mapped to the NIC Interventions, constituting the second step of the process of validation by experts. At the end of this stage, only six of the professionals performed the validation of all the data sent, which constituted the sample of experts of this study.

In the mapped data validation process, a round of the Delphi Technique was used for each step, once the minimum level of concordance, previously established between the evaluators in the first round, was reached. The concordance between the experts was verified using the Kappa index, defined as a measure of association to describe and test the degree of concordance (reliability and accuracy) of an evaluation ${ }^{(16)}$.

\section{Data Treatment and Analysis}

Descriptive analysis of the nursing diagnoses labels, of the nursing actions and of the demographic data of the nurses (age, gender, length of time since graduation) was performed using absolute frequencies and percentages. To evaluate the degree of concordance between the expert nurses the Kappa coefficient was applied. The nurse who presented the highest score was considered the gold standard according to the

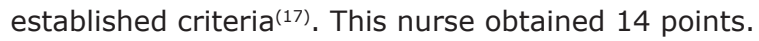

\section{Ethical aspects}

The study was approved by the Research Ethics Committee (COEP) of the Federal University of Minas Gerais (Protocol COEP No. 315/09).

\section{Results}

Among the 44 patients who comprised the sample, the majority, 30 (68\%), were female. Their ages ranged between 28 and 93 years, mean age 64 years, median of 66.5 and standard deviation of 17.5 years. There was a concentration in the care of elderly patients, with $68.3 \%$ of the patients 60 years of age or over.

\section{Identification of the nursing diagnoses registered in the clinical records}

For the 44 patients 1087 nursing diagnoses were formulated, with a mean of 8.5 diagnoses per patient. After performing the process of standardization of the content, 28 different nursing diagnoses labels were obtained (Table 1).

Table 1 - Nursing diagnoses labels identified in the clinical records of the patients hospitalized in the ICU. Belo Horizonte/MG, Brazil. 2010

\begin{tabular}{lll}
\hline \multicolumn{1}{c}{ Nursing diagnoses } & $\mathbf{n}$ & \% \\
\hline Bathing/hygiene self-care deficit & 44 & 100 \\
Risk for infection & 44 & 100 \\
Risk for constipation & 44 & 100 \\
Risk for impaired skin integrity & 43 & 98 \\
Intimate hygiene self-care deficit & 41 & 93 \\
Risk for unstable blood glucose level & 35 & 80 \\
Impaired bed mobility & 27 & 61 \\
Risk for relocation stress syndrome & 21 & 48 \\
Impaired skin integrity & 12 & 27 \\
Impaired tissue integrity & 11 & 25 \\
Ineffective airway clearance & 7 & 16 \\
Risk for aspiration & 7 & 16 \\
Anxiety & 5 & 11 \\
Ineffective protection & 5 & 11 \\
Excess fluid volume & 4 & 9 \\
Decreased cardiac output & 3 & 7 \\
Acute confusion & 2 & 5 \\
Acute pain & 2 & 5 \\
\hline
\end{tabular}

(continue...) 
Table 1 - (continuation)

\begin{tabular}{|c|c|c|}
\hline Nursing diagnoses & $\mathbf{n}$ & $\%$ \\
\hline $\begin{array}{l}\text { Imbalanced nutrition: less than body } \\
\text { requirements }\end{array}$ & 2 & 5 \\
\hline Ineffective breathing pattern & 2 & 5 \\
\hline $\begin{array}{l}\text { Risk for peripheral neurovascular } \\
\text { dysfunction }\end{array}$ & 2 & 5 \\
\hline Risk for loneliness & 2 & 5 \\
\hline Impaired gas exchange & 2 & 5 \\
\hline Chronic pain & 1 & 2 \\
\hline Impaired physical mobility & 1 & 2 \\
\hline Ineffective renal tissue perfusion & 1 & 2 \\
\hline Ineffective peripheral tissue perfusion & 1 & 2 \\
\hline Risk for falls & 1 & 2 \\
\hline
\end{tabular}

\section{Identification of the prescribed nursing actions}

For the 44 patients 2260 nursing actions were prescribed, with an average of 51 actions prescribed per patient during their hospitalization in the unit. After the process of standardization of the content 124 different nursing actions were obtained. Among the 124 prescribed nursing actions, 19 (15\%) presented a frequency greater than $50 \%$ (Table 2 ).

Table 2 - Prescribed nursing actions that presented a frequency greater than 50\%. Belo Horizonte/MG, Brazil. 2010

\begin{tabular}{|c|c|c|}
\hline Prescribed nursing actions & $\mathbf{n}$ & $\%$ \\
\hline Perform cutaneous hydration with body moisturizer after bathing & 44 & 100 \\
\hline Perform oral hygiene every 8 hours and when necessary & 44 & 100 \\
\hline Continuously monitor saturation levels, respiratory pattern and respiratory rate & 44 & 100 \\
\hline Keep head elevated if the hemodynamic status allows & 44 & 100 \\
\hline Date the equipment and replace it every $72 \mathrm{~h}$ & 44 & 100 \\
\hline Perform the rotation of oximetry sensor on digits every 2 hours & 39 & 89 \\
\hline Perform a bed bath every $24 \mathrm{~h}$ & 38 & 86 \\
\hline Keep the patient continuously monitored during the bed-bath & 34 & 77 \\
\hline Change peripheral venous access dressings every $24 \mathrm{~h}$ and if it is dirty and/or damp & 32 & 73 \\
\hline Inform the nurse of the presence of signs of inflammation at the insertion site of peripheral and/or central venous catheter & 32 & 73 \\
\hline Discard urine output every 2 hours & 30 & 68 \\
\hline Measure the urine output every 2 hours & 30 & 68 \\
\hline Measure axillary temperature every 2 hours & 30 & 68 \\
\hline Verify the permeability of peripheral venous access & 30 & 68 \\
\hline Check stasis every 6 hours & 28 & 64 \\
\hline Change intra-arterial pressure dressing every 24 hours and if it is dirty and/or damp & 27 & 61 \\
\hline Perform change of decubitus every 2 hours & 24 & 55 \\
\hline Measure and record blood pressure every 2 hours & 24 & 55 \\
\hline Periodically replace the fastening of nasoenteric feeding tube and observe signs of injury & 22 & 50 \\
\hline
\end{tabular}

It is noteworthy that $64(52 \%)$ of the nursing actions identified were prescribed for no more than $9 \%$ of patients.

\section{Mapping of the nursing diagnoses and actions to the basic human needs}

Among the 28 different nursing diagnoses labels formulated for the patients, 25 (89\%) were mapped to the physiological needs, $03(11 \%)$ to the psychosocial needs and none of the nursing diagnoses labels referred to the psychospiritual needs. The human psychobiological and psychosocial needs used in the mapping of the 28 different nursing diagnoses labels are presented in Table 3.
Table 3 - Human Psychobiological and Psychosocial Needs used in the mapping of the nursing diagnoses labels identified. Belo Horizonte/MG, Brazil. 2010

\begin{tabular}{lcc}
\hline \multicolumn{1}{c}{ Basic Human Need } & $\begin{array}{c}\text { ND mapped } \\
\text { (n) }\end{array}$ & $\begin{array}{c}\text { ND mapped } \\
(\%)\end{array}$ \\
\hline Psychobiological Needs & & \\
$\quad$ Vascular regulation & 5 & 20 \\
Physical Security/Environment & 4 & 16 \\
Oxygenation & 3 & 12 \\
Physical Integrity & 3 & 12 \\
Perception of the Sensory Organs & 2 & 8 \\
Physical Activity & 2 & 8 \\
Body Care & 2 & 8 \\
Elimination & 1 & 4 \\
Alimentation & 1 & 4 \\
Hydration & 1 & 4 \\
Neurological Regulation & 1 & 4 \\
Psychosocial Needs & & \\
Emotional Security & 3 & 100 \\
Total & 28 & 100 \\
\hline
\end{tabular}


The 124 different nursing actions identified were mapped to the basic human needs, as shown in Table 4. It was found that all the prescribed actions related to the psychobiological needs.

Table 4 - Basic Human Needs used in the mapping of the prescribed nursing actions. Belo Horizonte/MG, Brazil. 2010

\begin{tabular}{lcc}
\hline \multicolumn{3}{c}{ Psychobiological Human Needs } \\
\hline BHN & $\begin{array}{c}\text { Nursing actions } \\
\text { mapped (n) }\end{array}$ & $\begin{array}{c}\text { Nursing actions } \\
\text { mapped (\%) }\end{array}$ \\
\hline Physical Security/Environment & 32 & 26 \\
Physical Integrity & 31 & 25 \\
Vascular Regulation & 24 & 19 \\
Elimination & 22 & 18 \\
Alimentation & 6 & 5 \\
Body Care & 5 & 4 \\
Oxygenation & 2 & 2 \\
Thermal Regulation & 1 & 1 \\
Neurological Regulation & 1 & 1 \\
Total & 124 & 100 \\
\hline
\end{tabular}

\section{Mapping of the nursing actions to the Interventions proposed by the NIC}

The nursing actions prescribed were mapped to the NIC Interventions. All the actions could be linked to the NIC Interventions. However, the nursing actions prescribed for the 44 patients in the sample were related to only $42(8 \%)$ Interventions proposed by the NIC among the 514 available. The NIC is composed of 7 domains and 30 classes of nursing interventions. It was observed that the nursing actions prescribed for the patients were contemplated in only three of the domains of the NIC. It was verified that the nursing actions identified comprehended only 10 (33\%) of the classes of the NIC Interventions. The largest number of NIC Interventions mapped, 23 (55\%), were found in the complex physiological domain. These were distributed in the classes: drug management, neurologic management, respiratory management, skin/wound management, and tissue perfusion management. Another 14 (33\%) were in the physiological basic domain, distributed in the classes elimination management, immobility management, selfcare facilitation and nutrition support. In the security domain, there were 5 (12\%) interventions, all in the risk control class. Among the 42 NIC interventions used in the cross-mapping performed, 4 (9.5\%) were present in more than one class.

\section{Validation of the nursing diagnoses and actions mapped}

Regarding the validation of the nursing diagnoses labels and actions, all the nurses who formed the sample met the inclusion criteria, presenting scores greater than or equal to 5 according to the established criteria(17). All the professionals worked and lived in Belo Horizonte, MG, and were female. A degree of concordance of $100 \%$ was found (Kappa=1.0) among the group of experts in the validation process of the diagnoses titles and the nursing actions.

\section{Discussion}

The majority $(68.3 \%)$ of the patients were concentrated in the age group greater than or equal to 60 years of age. The mean age of the ICU patients has increased in recent years and will further increase with the aging of the population in general. In Western countries, the percentage of individuals over 65 years of age represents $18 \%$ of the general population, accounting for $45.5 \%$ of hospital admissions ${ }^{(18)}$. For the 44 patients 1087 NDs and 2260 nursing actions were formulated. There was a mean of 8.5 diagnoses produced per patient, similar to that described in the literature in which the mean of diagnoses reported per patients were 6.9 and 8 respectively ${ }^{(19-20)}$.

In this study, only 10 of the nursing diagnoses labels formulated were risk diagnoses, 2 of these being identified in all patients, namely "risk for constipation" and "risk for infection". The real diagnoses describe responses already present in the patients and those of risk describe responses that may develop. The latter is supported by risk factors that contribute to increased vulnerability to pathogens ${ }^{(5)}$. The fact that the majority of the nursing diagnoses were classified as real is evidence that the nursing care in the ICU should be focused on the recovery of health. However, the identification of risk diagnoses also indicates that there is concern on behalf of the nurses regarding the preventive aspects in the patient care ${ }^{(19)}$. In an ICU patients are at risk of death, leaving nurses to recognize the initial signs of deviation from normality in order to implement quality nursing care.

A mean of 51 prescribed nursing actions per patient was identified. The actions identified were not related to the nursing diagnoses formulated, a situation also reported in another study(21). According to the author 
this could be explained either because a large number of necessary actions exist that did not help to resolve the problem or because the nurse did not record the diagnosis, but thought about it, did the clinical rationale for their formulation and proposed nursing actions aimed at the solution ${ }^{(21)}$. Among the 28 different nursing diagnoses labels mapped to the BHN, 25 (89\%) were related to the psychobiological needs and $3(11 \%)$ to the psychosocial needs. However, all the nursing actions were mapped to the psychobiological needs. This fact demonstrates that nursing diagnoses were formulated that did not present prescribed nursing actions to improve or solve the nursing problems identified. Despite the identification of only three nursing diagnoses labels mapped to the psychosocial needs this is important data, since in the vast majority of the services the nurses still perform the care directed towards a physician-centered model.

It is comprehended that, depending on the severity of the physical health status of patients hospitalized in an ICU, the nursing staff should prioritize the care according to the psychobiological needs affected. However, it is noteworthy that the needs are interrelated and constitute part of an indivisible whole of the human being so that, when one is manifested, they all suffer some degree of alteration(4). All the prescribed nursing actions were mapped to the NIC Interventions. It is understood, therefore, that the NIC Interventions contemplate the prescribed nursing actions and can be used to represent the practice of nursing in the context of an ICU. Of the 124 nursing actions, 37 (30\%) were mapped to more than one NIC intervention. When the different NIC Interventions used in the crossmapping and their relationship with the domains of this classification were analyzed, it was verified that these comprehended only three of seven domains, with the majority located in the complex physiological domain $23(55 \%)$, followed by the basic physiological domain $14(33 \%)$ and the security domain $5(12 \%)$.

In relation to the essential nursing interventions by the specialty areas proposed by the NIC, it was verified that among the 54 interventions presented for the area Nursing in Intensive Care, only 10 (24\%) of the 42 different NIC Interventions encountered in this study, coincided with those presented in the classification. It was verified that the sample of experts of this study proved to be qualified, combining practical experience (the minimum length of practical experience was 4 years) with experience in academic and research activities.

\section{Conclusions}

This study allowed the identification of the more frequent nursing diagnoses labels and actions in the patients hospitalized in an Adult ICU. The Nurses formulated 1087 diagnoses and 2260 nursing actions for the 44 patients whose clinical records were analyzed, with many repeated. After performing the process of standardization of the content, 28 different nursing diagnoses labels and 124 different nursing actions were obtained. The nursing diagnoses labels and actions were mapped to the BHN Theory and the nursing actions were also mapped to the NIC Interventions. Concordance of $100 \%$ was obtained between the nurses in the mapping validation process, both for the nursing diagnoses labels and for the nursing actions.

Among the nursing diagnosis labels, 7 were formulated for more than $50 \%$ of the patients, being that the diagnoses labels of "risk for infection", "Bathing/ hygiene self-care deficit" and "risk for constipation" were identified by the nurses for all of the patients. The majority of the nursing diagnoses titles identified in this study were also found in the literature, confirming that they are common to the clinical practice of the ICU nurse. The nursing diagnoses labels were mapped to the BHN theory, with only three related to the psychosocial needs and none to the psychospiritual needs.

Regarding the 124 nursing actions identified, 19 presented frequencies higher than $50 \%$. Of these, only 5 were prescribed for all the patients. All the nursing actions identified were mapped to the psychobiological $\mathrm{BHN}$ and also to the NIC Interventions. However, the actions were related to only 42 NIC Interventions, among the 514 available. The 124 different nursing actions identified were contemplated in only three of the seven NIC domains, with 23 (55\%) associated with the Complex Physiological domain. The predominance of actions in the complex physiological domain leads to the conclusion that the practice of ICU nursing is intimately linked to the resolution of problems that require interventions to support the care of the homeostatic regulation of the individual. As nursing care seeks to provide care focused on integrality in the care, it is suggested that similar studies in ICUs of other locations and different contexts/specialties are conducted in order to accompany the evolution of the diagnoses and of the nursing prescriptions in relation to the identification and care of other BHN beyond the psychobiological needs. 


\section{References}

1. Garcia TR, Nóbrega MML. Processo de enfermagem e os sistemas de classificação dos elementos da prática profissional: instrumentos metodológicos e tecnológicos do cuidar. $7^{\circ}$ Simpósio Nacional de Diagnósticos de Enfermagem, 2004; Belo Horizonte, MG. Belo Horizonte: ABEn; 2004. $231 \mathrm{p}$.

2. Dochterman JM, Bulechek GM. Classificação das intervenções de enfermagem (NIC). 4. ed. Porto Alegre: Artmed; 2008. 988 p.

3. Nascimento ERP do, Trentini M. O cuidado de enfermagem na unidade de terapia intensiva (UTI): teoria humanística de Paterson e Zderad. Rev. LatinoAm. Enfermagem. [periódico na Internet]. mar-abr 2004 [acesso 14 junho 2010]; 12(2):250-7. Disponível em: http://www.scielo.br/scielo.php?script=sci_artt ext\&pid=S010411692004000200015\&lng=pt. doi: 10.1590/S0104-11692004000200015.

4. Horta WA. Processo de enfermagem. São Paulo: EPU Editora da Universidade de São Paulo; 1979. 99 p.

5. North American Nursing Diagnosis Association. Diagnósticos de enfermagem da NANDA: definições e classificação 2009-2011. Porto Alegre: Artmed; 2009. $456 \mathrm{p}$.

6. Good PI. Permutation Tests: a pratical guide to resampling methods for testing hyphoteses. 2nd. ed. New York: Springer-Verlag; 1994. (Springer series in statistics).

7. Ross SM. Simulation. 4th. Ed. New York: Elsevier; 2006.

8. Pavel S, Nolet D. Manual de terminologia. Canadá: Public Words and Govermment Services, 2001. 166 p.

9. Coenen A, Ryan $P$, Sutton J. Mapping nursing interventions from a hospital information system to the nursing interventions classification (NIC). Nurs Diagn. 1997;8(4):145-51.

10. Moorhead S, Delaney C. Mapping nursing intervention data into the nursing interventions classification (NIC): process and rules. Nurs Diagn. 1997;8(4):137-44.

11. Goodman CM. The Delphi Technique: a critique. J Adv Nurs. 1987;12(3):729-34.

12. Keeney S, Hasson F, Mckenna H. Consulting the oracle: ten lessons from the Delphi Technique in nursing research. J Adv Nurs. 2006;2(53):205-12.

13. Grant JS, Kinney MR. Using the Delphi technique to examine content validity of nursing diagnosis. Nurs Diag. $1992 ; 3(1): 12-22$.
14. Mancussi AC. Assistência ao binômio paciente/família na situação de lesão traumática da medula espinhal. Rev. Latino-Am. Enfermagem. 1998;6(4):67-73.

15. Benedet AS, Bub MBC. Manual de diagnóstico de enfermagem: uma abordagem baseada na teoria das necessidades humanas básicas e na classificação diagnóstica da NANDA. 2. ed. ver. Florianópolis: Bernúncia; 2001.

16. Kotz S, Johnson NL. Encyclopédia of statiscal sciences. New York: John Wiley; 1983. p. 352-4.

17. Fehring RJ. Methods to validate nursing diagnoses. Heart \& Lung. 1987;16(6):625-9.

18. Nagappan R, Parkin G. Geriatric critical care. Crit Care Clin. 2003;19(2):253-70.

19. Lucena AF. Mapeamento dos diagnósticos e intervenções de enfermagem de uma unidade de terapia intensiva [dissertação]. São Paulo: Escola Paulista de Medicina da Universidade Federal de São Paulo; 2006.

20. Pasini D, Alvim I, Kanda L, Mendes RSP, Cruz DALM da. Diagnósticos de enfermagem de pacientes em unidades de terapia intensiva. Rev Esc Enferm USP. 1996;30(3):501-18.

21. Ribeiro FG. Estudo comparativo de dois métodos de registro de diagnósticos e intervenções de enfermagem em pacientes durante o transoperatório de cirurgia de revascularização do miocárdio [tese]. São Paulo: Faculdade de Medicina da Universidade de São Paulo; 2006.

Received: Dec. 24th 2010 Accepted: May $17^{\text {th }} 2011$ 